\title{
COULD COVID-19 BE A HEMOGLOBINOPATHY?
}

\author{
Tania Ahmed Shakoori, Muhammad Mansoor Hafeez and Arif Malik \\ Institute of Molecular Biology and Biotechnology (IMBB), University of Lahore, New Campus, \\ Defense Road 1, KM off Raiwind Road, Lahore, Pakistan
}

\begin{abstract}
SUMMARY - The world is struggling to deal with the corona pandemic. Effective therapies are still awaited due to the lack of understanding of the pathophysiological mechanism of the disease. Bearing recent research and clinical observations in mind, the authors propose a novel physiological mechanism of COVID-19 and explain development of COVID-19 related acute respiratory distress syndrome (ARDS) secondary to COVID-19 related hemoglobinopathy. It is a consistent observation that the radiological picture of COVID-19 related ARDS bears more resemblance to high altitude pulmonary edema (HAPE) than typical ARDS. There has been great controversy regarding this proposed similarity. The main argument from those objecting to this comparison is that the etiology is hypoxia in case of HAPE and inflammation in COVID-19 related ARDS. We propose that considering the recent bioinformatics prediction models, COVID-19 might first infect red blood cells via CD147 and cause hemoglobin damage. The resulting hypoxemia may cause pulmonary hypoxic vasoconstriction leading to HAPE-like lung lesions. The now introduced alveolar hypoxia further exaggerates hemoglobinopathy hypoxemia leading to a vicious cycle. In this review, the authors recommend laboratory experiments to prove these hypotheses. The proposed physiological mechanism has significant therapeutic implications. If proven, the authors suggest the use of exchange transfusion as adjunct therapy and development of anti-CD147 drugs.
\end{abstract}

Key words: COVID-19; High altitude pulmonary embolism; High altitude pulmonary edema, pathophysiology; Acute respiratory distress syndrome; CD147

\section{Introduction}

Coronavirus disease 2019 (COVID-19) is a global pandemic caused by a novel coronavirus 2 (SARS$\mathrm{CoV}-2)$. The most common presentation is respiratory disease ranging from mild flu-like illness to severe pneumonia, but a significant number of patients develop septic shock and multiple organ failure ${ }^{1}$. The causative agent is the severe acute respiratory syndrome coronavirus 2 (SARS-CoV-2), which was first identified in China but rapidly spread by human-tohuman transmission to the rest of the world. Each day, the number of cases and deaths rise. The struggle for effective treatment is hindered by the lack of under-

Correspondence to: Dr. Tania Ahmed Shakoori, Institute of Molecular Biology and Biotechnology (IMBB), University of Lahore, New Campus, Defense Road 1, KM off Raiwind Road, Lahore, Pakistan E-mail: tania.ahmed@imbb.uol.edu.pk

Received August 27, 2020, accepted November 20, 2020 standing of the pathophysiology of this newly emerged viral disease ${ }^{2}$.

The illness ranges from mild flu-like symptoms to severe acute respiratory distress syndrome (ARDS). Other organ involvements have not been reported frequently. Once the patient reaches the stage of ARDS, they are likely to be admitted to the intensive care unit (ICU) and the risk of mortality rises sharply ${ }^{3}$. However, ARDS caused by this disease is not typical. It has been observed that there are significant differences between COVID-19 related ARDS and typical ARDS. Clinical symptoms are inconsistently milder compared with the severity of laboratory and imaging findings ${ }^{4}$. According to the ARDS Berlin Criteria, for a patient to be diagnosed as having ARDS, the onset must be within 1 week of the symptom onset ${ }^{5}$. In contrast, COVID-19 induced ARDS occurs after 8-12 days. Computed tomography (CT) findings of COVID-19 
related ARDS also diverge from the typical picture. In acute phase of typical ARDS, CT scan shows dense consolidation in the most dependent regions, and ground-glass appearance in the non-dependent regions of the lung. In COVID-19, CT scans show multifocal bilateral patchy shadows along with either ground-glass opacities and/or consolidation in some cases $^{6}$. Furthermore, lung compliance is not reduced and oxygenation index does not correlate with disease severity as in typical ARDS ${ }^{4}$. Another queer characteristic of COVID-19 patients is the phenomenon of 'silent hypoxemia', where despite low levels of $\mathrm{PO}_{2}$ and hemoglobin oxygen saturation $\left(\mathrm{SO}_{2}\right)$, the patient does not exhibit signs of respiratory distress ${ }^{7}$. It has been proposed that this might be due to failure of the body's homeostatic $\mathrm{O}_{2}$-sensing system (HOSS), such as defect of peripheral chemoreceptors ${ }^{8}$. Indeed, it has been shown that angiotensin converting enzyme 2 (ACE2) receptors are expressed on the cells of the carotid body ${ }^{9}$, and COVID-19 can theoretically infect the carotid bodies. Furthermore, carotid body sensitivity to hypoxemia, in many subjects, is determined by accompanying hypercapnia ${ }^{10,11}$, which is not seen in COVID-19 patients ${ }^{7}$. It is conceivable that the body's ability to detect hypoxemia may be compromised. This evidence suggests that the ARDS of COVID-19 differs significantly from typical ARDS.

Liu and Li have recently demonstrated via bioinformatics prediction analyses that SARS-CoV-2 can attack the beta chain of hemoglobin. They also propose that the product of open reading frame 8 (ORF8) binds to the porphyrin of heme and displaces iron ${ }^{12}$. It has further been shown that CD147, the surface antigen of red blood cells (RBCs) determining the $\mathrm{OK}$ blood group ${ }^{13}$, is the receptor on $\mathrm{RBC}$ s which grants access to the COVID-19 virus into the red cell ${ }^{14}$. CD147 has been previously implicated in facilitating cyto-invasion of other viruses including $\mathrm{HIV}^{15}$, measles virus ${ }^{16}$, SARS-CoV virus ${ }^{17}$, several bacteria such as Listeria monocytogenes ${ }^{18}$, and even protozoans such as Plasmodium falciparum which causes malaria ${ }^{19}$.

The authors propose that after gaining entry into the RBCs, viral proteins bind the beta chains of hemoglobin, produce a change in molecular configuration of the porphyrin ring and reduce the affinity of hemoglobin for $\mathrm{O}_{2}{ }^{12}$. This phenomenon can conceivably produce false readings of $\mathrm{O}_{2}$ saturation by pulse oximetry, similar to the scenario of carbon monoxide $(\mathrm{CO})$ poi- soning. The readers are reminded that in $\mathrm{CO}$ poisoning, the $\mathrm{CO}$ molecule competes with $\mathrm{O}_{2}$ on the hemoglobin binding sites. It displaces oxygen from the porphyrin rings, but produces a change in molecular configuration similar to oxyhemoglobin. The pulse oximeter used in clinical practice does not directly measure the amount of oxygen bound to hemoglobin, rather it estimates the $\mathrm{O}_{2}$ saturation, by measuring light absorbance through a well perfused organ such as earlobe or finger. Since light absorbance changes are determined by molecular conformation of the hemoglobin molecule, and factors other than $\mathrm{O}_{2}$ can bind to hemoglobin and produce similar conformational changes, the pulse oximeter may show a falsely higher saturation. As an example, when there is $70 \%$ carboxyhemoglobin $(\mathrm{COHb})$ and actual $\mathrm{O}_{2}$ saturation is only $30 \%$, pulse oximeter will still measure $90 \%$ of hemoglobin saturation with oxygen $^{20}$. Thus, if hemoglobin has been damaged or altered in some way as a result of the viral protein binding the polypeptide chains of the molecule, it may be that $\mathrm{SO}_{2}$ reading might not depict the true picture of decreased oxygen content of the blood. The authors propose that this might be the situation in the early stage of the disease before involvement of the lungs. As to why this reduced oxygen content of the blood does not produce dyspnea, it may be related to the physiological mechanism of peripheral chemoreceptors, as explained below. In the early stage of the disease, prior to lung involvement, $\mathrm{PO}_{2}$, which is determined by dissolved oxygen, remains normal. It has long been known that even after $50 \%$ of hemoglobin is replaced with carboxyhemoglobin, the ventilation does not change. This is because it is the dissolved $\mathrm{O}_{2}$ and not the total oxygen content of the blood, which is sensed by peripheral chemoreceptors ${ }^{21}$. Therefore, the sensation of dyspnea would not be produced if hemoglobin saturation has been reduced due to viral infection as proposed above.

The radiographic resemblance of ARDS of COVID-19 with high altitude pulmonary embolism (HAPE) has been a consistent observation and a matter of some controversy recently. Some researchers notice similar radiographic presentation of HAPE and COVID-19 related ARDS and go as far as to propose the use of acetazolamide and nifedipine, which are used in the management of HAPE as adjuvant therapies ${ }^{22-24}$. Others have come out vehemently challenging these ideas ${ }^{4,8,25-27}$. The main points put forth by those raising objections to the comparison of HAPE with COVID-19 related ARDS are as follows: first, it is argued that lung injury 


\section{COVD-19 galns enty
Into RBC via CDI47}

Viral protelns attach to hemogloblin,
decreased afilintily of $\mathrm{Hb}$ for $\mathrm{O} 2$

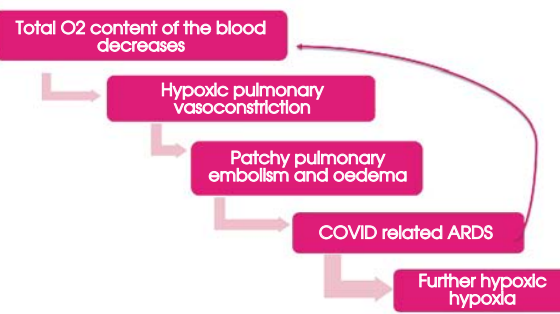

Fig. 1. Proposed pathophysiological mechanism for COVID-19: hemoglobinopathy related hypoxemia leads to secondary pulmonary involvement. However, as lungs get involved, alveolar hypoxia contributes further to hypoxemia leading to a vicious cycle of oxygen deprivation in the body.

in COVID-19 related ARDS is due to inflammation, not hypoxia. Secondly, it is argued that therapeutic management of HAPE is likely to harm COVID-19 patients. While we agree that caution needs to be exercised with regards to novel medication, we propose that chronic inflammation may not be the primary cause of lung injury in COVID-19 related ARDS. HAPE is caused by extreme hypoxic pulmonary vasoconstriction in response to low atmospheric $\mathrm{O}_{2}$ at high altitudes. Pulmonary artery pressure rises in areas of vasoconstriction, and blood is redirected to other areas of pulmonary vasculature leading to increased pulmonary capillary hydrostatic pressure, leakage and patchy consolidation ${ }^{28}$. We propose that hypoxemia resulting from damaged hemoglobin would tend to produce hypoxic pulmonary vasoconstriction in the absence of alveolar hypoxia, leading to lung damage similar to HAPE. Figure $1 \mathrm{ex}-$ plains our hypothesis further.

The above cited model of RBC infection, hemoglobin dysfunction, reduced $\mathrm{O}_{2}$ content, pulmonary hypoxic vasoconstriction leading to HAPE like lung damage is not that far off. Plasmodium falciparum enters $\mathrm{RBC}$ using same receptor $\mathrm{CD} 147^{19}$, attacks hemoglobin ${ }^{29}$, causes right shift in the Hb-dissociation curve $^{30}$, and in severe cases can cause ARDS like lung pathology in up to $25 \%$ of malaria patients ${ }^{31}$.

\section{Testing the Hypothesis}

A simple experiment may be conducted to demonstrate that blood which the pulse oximeter shows to be saturated, might in fact contain deoxyhemoglobin which has assumed relaxed molecular configuration ${ }^{20}$, possibly due to attachment of viral proteins as suggested by bioinformatics modeling ${ }^{12}$.

Blood may be taken from a COVID-19 patient showing a certain level of saturation, say $90 \%$. At the same time, $90 \%$ saturated blood may be taken from another healthy individual with matched hemoglobin concentration. These blood samples can be exposed to high concentration of carbon monoxide or sodium dithionite $^{32}$ in a closed chamber which also accommodates an oxygen sensor. These chemicals have high affinity for hemoglobin and tend to cause detachment of $\mathrm{O}_{2}$ from the $\mathrm{Fe}$ of porphyrin rings. After adequate exposure, the amount of oxygen released from COVID-19 patient's blood should be substantially lower than that of the healthy subject's blood. The experiment may be repeated several times for statistical accuracy. This simple experiment can help detect defective RBCs, meaning RBCs which pulse oximeter is falsely showing to be adequately saturated with $\mathrm{O}_{2}$. Such patients can be candidates for exchange therapy in addition to routine corona management. A further future direction may be development of a pulse oximeter to sense the wavelength of light reflected by hemoglobin bound to viral protein in a manner similar to the development of Pulse CO-Oximeter ${ }^{33}$.

\section{Conclusions and Implications for Therapy}

Even though direct evidence from wet lab is not available as yet, it is still critical that this mechanism in the pathophysiology of COVID-19 be considered and further investigated. If the total $\mathrm{O}_{2}$ content is reduced because of hemoglobinopathy and pulse oximeter readings are not reliable, giving more oxygen to the patient will not prove effective at all. An effective treatment in this scenario could be exchange transfusion, which would replace defective infected $\mathrm{RBCs}$ with healthy ones. As a matter of fact, this was proposed as an adjunct therapy for severe malaria by several researchers in the $1990 \mathrm{~s}^{34-37}$, before the Center for Disease Control (CDC) withdrew the recommendation in favor of more effective drug therapies ${ }^{38}$. Furthermore, considering the similarities between malaria and COVID-19, it may perhaps be prudent to reconsider trials of hydroxychloroquine, and assess if benefits outweigh the risks. Finally, drugs such as Meclizumab, 
which block CD147 and may prevent infection of the cells by the coronavirus, may be considered for further randomized control trials. This has already been suggested by several researchers ${ }^{39,40}$.

The current pandemic has presented the medical community with a unique conundrum of trying to develop therapies for a disease the pathophysiology of which is being uncovered in real time. In this context, the authors believe there is sufficient evidence to at least focus research, and eventually design therapies on the premise that COVID-19 may primarily be a hemoglobinopathy with pulmonary involvement as a secondary phenomenon.

\section{References}

1. Cao X. COVID-19: immunopathology and its implications for therapy. Nat Rev Immunol. 2020;20(5):269-70. https://doi. org/10.1038/s41577-020-0308-3

2. Tay MZ, Poh CM, Rénia L, MacAry PA, Ng LF. The trinity of COVID-19: immunity, inflammation and intervention. Nat Rev Immunol. 2020;20:1-12. https://doi.org/10.1038/s41577020-0311-8

3. Burki TK. Coronavirus in China. Lancet Resp Med. 2020; 8(3):238. doi: 10.1016/S2213-2600(20)30056-4

4. Strapazzon G, Hilty MP, Bouzat P, Pratali L, Brugger H, Rauch S. To compare the incomparable: COVID-19 pneumonia and high altitude disease. Eur Resp J. 2020;55:2001362. https://doi.org/10.1183/13993003.01362-2020

5. Force ADT, Ranieri V, Rubenfeld G, Thompson B, Ferguson $\mathrm{N}$, Caldwell E. Acute respiratory distress syndrome. JAMA. 2012;307(23):2526-33. doi: 10.1001/jama.2012.5669

6. Chung M, Bernheim A, Mei X, Zhang N, Huang M, Zeng X, et al. CT imaging features of 2019 novel coronavirus (2019nCoV). Radiology.2020;295(1):202-7.https://doi.org/10.1148 /radiol.2020200230

7. Tobin MJ, Laghi F, Jubran A. Why COVID-19 silent hypoxemia is baffling to physicians. Am J Resp Crit Care Med. 2020;202(3):356-60. doi: 10.1164/rccm.202006-2157CP

8. Archer SL, Sharp WW, Weir EK. Differentiating COVID-19 pneumonia from acute respiratory distress syndrome (ARDS) and high altitude pulmonary edema (HAPE): therapeutic implications. Circulation. 2020;142:101-4. https://doi.org/10. 1161/CIRCULATIONAHA.120.047915Circulation

9. Fung ML. Expressions of angiotensin and cytokine receptors in the paracrine signaling of the carotid body in hypoxia and sleep apnea. Resp Physiol Neurobiol. 2015;209:6-12. https:// doi.org/10.1016/j.resp.2014.09.014

10. Moosavi SH, Golestanian E, Binks AP, Lansing RW, Brown R, Banzett RB. Hypoxic and hypercapnic drives to breathe generate equivalent levels of air hunger in humans. J Appl Physiol. 2003;94(1):141-54. doi: 10.1152/japplphysiol.00594.2002
11. Mohan R, Duffin J. The effect of hypoxia on the ventilatory response to carbon dioxide in man. Resp Physiol. 1997;108 (2):101-15. https://doi.org/10.1016/S0034-687(97)00024-8

12. Liu W, Li H. COVID-19 attacks the 1-beta chain of hemoglobin and captures the porphyrin to inhibit human heme metabolism. ChemRxiv. Preprint. 2020;10(04). https://doi.org/ 10.26434/chemrxiv.11938173.v9

13. Spring FA, Holmes CH, Simpson KL, Mawby WJ, Jules Mattes M, Okubo Y, et al. The Oka blood group antigen is a marker for the M6 leukocyte activation antigen, the human homolog of OX-47 antigen, basigin and neurothelin, an immunoglobulin superfamily molecule that is widely expressed in human cells and tissues. Eur J Immunol. 1997;27(4):891-7. doi: 10.1002/eji.1830270414

14. Wang K, Chen W, Zhou Y-S, Lian J-Q, Zhang Z, Du P, et al. SARS-CoV-2 invades host cells via a novel route: CD147spike protein. bioRxiv 2020.03.14.988345. doi: https://doi. org/10.1101/2020.03.14.988345

15. Pushkarsky T, Zybarth G, Dubrovsky L, Yurchenko V, Tang H, Guo H, et al. CD147 facilitates HIV-1 infection by interacting with virus-associated cyclophilin A. Proc Natl Acad Sci. 2001; 98(11):6360-5. doi: 10.1073/pnas.111583198

16. Watanabe A, Yoneda M, Ikeda F, Terao-Muto Y, Sato H, Kai C. CD147/EMMPRIN acts as a functional entry receptor for measles virus on epithelial cells. J Virol 2010;84(9):4183-93. doi: 10.1128/JVI.02168-09

17. Chen Z, Mi L, Xu J, Yu J, Wang X, Jiang J, et al. Function of HAb18G/CD147 in invasion of host cells by severe acute respiratory syndrome coronavirus. J Infect Dis. 2005;191(5): 755-60. https://doi.org/10.1086/427811

18. Till A, Rosenstiel P, Bräutigam K, Sina C, Jacobs G, Oberg $\mathrm{H}-\mathrm{H}$, et al. A role for membrane-bound CD147 in NOD2mediated recognition of bacterial cytoinvasion. J Cell Sci. 2008;121(4):487-95. doi: 10.1242/jcs.016980

19. Zhang M-Y, Zhang Y, Wu X-D, Zhang K, Lin P, Bian H-J, et al. Disrupting CD147-RAP2 interaction abrogates erythrocyte invasion by Plasmodium falciparum. Blood. 2018;131(10):111121. doi: 10.1182/blood-2017-08-802918

20. Barker SJ, Tremper KK, Hyatt J. Effects of methemoglobinemia on pulse oximetry and mixed venous oximetry. Anesthesiology. 1989;70(1):112-7. doi: 10.1097/00000542-19890100000021

21. Santiago T, Edelman NH. Mechanism of the ventilatory response to carbon monoxide. J Clin Invest. 1976;57(4):977-86. doi: 10.1172/JCI108374

22. Solaimanzadeh I. Acetazolamide, nifedipine and phosphodiesterase inhibitors: rationale for their utilization as adjunctive countermeasures in the treatment of coronavirus disease 2019 (COVID-19). Cureus. 2020;12(3):e7343. doi: 10.7759/cureus. 7343

23. Flaherty G, Hession P. Unravelling the pathogenesis of severe COVID-19 pneumonia: are there possible insights from high altitude. Int J Travel Med Glob Health. 2020;8(2):89-90. doi: 10.34172/IJTMGH.2020.14 
24. Kyle-Sidell C. COVID-19 lung injury and 'typical' ARDS: the danger of presumed equivalency. Ann Am Thorac Soc. 2020;17 (9):1171-2. https://doi.org/10.1513/AnnalsATS.202005-405LE

25. Luks AM, Freer L, Grissom CK, McIntosh SE, Schoene RB, Swenson ER, et al. COVID-19 lung injury is not high altitude pulmonary edema. High Alt Med Biol. 2020;21(2):192-3. doi: 10.1089/ham.2020.0055

26. Luks AM, Swenson ER. COVID-19 lung injury and high altitude pulmonary edema: a false equation with dangerous implications. Ann Am Thorac Soc. 2020;17(8):918-21. doi: 10.1513/AnnalsATS.202004-327CME

27. Brugger H, Basnyat B, Ellerton J, Hefti U, Strapazzon G, Zafren K. COVID-19 lung injury is different from high altitude pulmonary edema (Re: High Alt Med Biol [Epub ahead of print]. doi: 10.1089/ham. 2020.0055). High Alt Med Biol. 2020;21(2):204-5. doi: 10.1089/ham.2020.0061

28. Swenson ER, Maggiorini M, Mongovin S, Gibbs JSR, Greve I, Mairbäurl H, et al. Pathogenesis of high-altitude pulmonary edema: inflammation is not an etiologic factor. JAMA. 2002; 287(17):2228-35. doi: 10.1001/jama.287.17.2228

29. Kamchonwongpaisan S, Samoff E, Meshnick S. Identification of hemoglobin degradation products in Plasmodium falciparum. Mol Biochem Parasitol. 1997;86(2):179-86. https://doi.org/ 10.1016/S0166-6851(97)02855-7

30. Dasgupta R, Verma RS, Ahlawat S, Uppal A, Gupta PK. Studies on erythrocytes in malaria infected blood sample with $\mathrm{Ra}-$ man optical tweezers. J Biomed Optics. 2011;16(7):077009. https://doi.org/10.1117/1.3600011

31. Elzein F, Mohammed N, Ali N, Bahloul A, Albadani A, Alsherbeeni N. Pulmonary manifestation of Plasmodium falciparum malaria: case reports and review of the literature. Respir Med Case Rep. 2017;22: 83-6. doi:10.1016/j.rmcr.2017.06.014

32. Vandegriff $\mathrm{K}, \mathrm{O} 1$ son $\mathrm{J}$. The kinetics of $\mathrm{O} 2$ release by human red blood cells in the presence of external sodium dithionite. J Biol Chem. 1984;259(20):12609-18. PMID: 6490633
33. Sebbane M, Claret P-G, Mercier G, Lefebvre S, Théry R, Dumont $\mathrm{R}$, et al. Emergency department management of suspected carbon monoxide poisoning: role of pulse CO-oximetry. Resp Care. 2013;58(10):1614-20. doi: 10.4187/respcare.02313

34. Miller KD, Greenberg AE, Campbell CC. Treatment of severe malaria in the United States with a continuous infusion of quinidine gluconate and exchange transfusion. N Engl J Med. 1990;322:58-9. doi: 10.1056/NEJM199001043220113

35. Gulprasutdilog S, Chongkolwatana V, Buranakitjaroen P, Jaroonvesama N. Exchange transfusion in severe falciparum malaria. J Med Assoc Thai. 1999;82(1):1-8. PMID: 10087731

36. Van den Ende J, Moorkens G, Van Gompel A, Demey H, Lins $\mathrm{R}$, Maldague $\mathrm{P}$, et al. Twelve patients with severe malaria treated with partial exchange transfusion. Comparison between mathematically predicted and observed effect on parasitaemia. Trop Geogr Med. 1994;46(6):340. PMID: 7892699

37. Macallan DC, Pocock M, Robinson GT, Parker-Williams J, Bevan DH. Interactive clinical case reports: red cell exchange, erythrocytapheresis, in the treatment of malaria with high parasitaemia in returning travellers. Trans R Soc Trop Med Hyg. 2000;94(4):353-6. https://doi.org/10.1016/S0035-9203 (00)90101-9

38. Center for Disease Control and Prevention. Exchange transfusion for treatment of severe malaria no longer recommended. 2013. Available from: https://www.cdc.gov/malaria/new info/2013/exchange_transfusion.html Accessed 13-09-2020

39. Ulrich H, Pillat MM. CD147 as a target for COVID-19 treatment: suggested effects of azithromycin and stem cell engagement. Stem Cell Rev Rep. 2020;20:1-7. doi: 10.1007/s12015020-09976-7

40. Bian H, Zheng Z-H, Wei D, Zhang Z, Kang W-Z, Hao C-Q, et al. Meplazumab treats COVID-19 pneumonia: an open-labelled, concurrent controlled add-on clinical trial. MedRxiv. 2020. doi: https://doi.org/10.1101/2020.03.21.20040691

\section{Sažetak}

\section{BI LI COVID-19 MOGLA BITI HEMOGLOBINOPATIJA?}

\section{T. Ahmed Shakoori, M. Mansoor Hafeez i A. Malik}

Cijeli svijet se bori kako bi svladao pandemiju koronavirusa. Patofiziološki mehanizam ove bolesti i dalje je nepoznat, što znači da se učinkoviti lijekovi tek očekuju. Vodeći računa o novijim istraživanjima i kliničkim zapažanjima, autori predlažu novi fiziološki mehanizam bolesti COVID-19 i objašnjavaju razvoj sindroma akutnog respiracijskog distresa (ARDS) nakon hemoglobinopatije povezane s COVID-19. Dosljedno se bilježi da radiološka slika hemoglobinopatije povezane s COVID-19 ima više sličnosti s visinskim plućnim edemom (HAPE) negoli s tipičnim ARDS. Ova sličnost izaziva velika proturječja. Glavni argument onih koji se protive ovoj usporedbi jest da je etiologija kod HAPE hipoksija, a kod ARDS povezanog s COVID-19 je to upala. Mi pretpostavljamo da bi, uzimajući u obzir novije bioinformatičke modele predviđanja, COVID-19 mogao najprije zaraziti eritrocite putem CD147 i uzrokovati oštećenje hemoglobina. Tako nastala hipoksemija može uzrokovati plućnu hipoksičnu vazokonstrikciju, što onda dovodi do oštećenja pluća sličnih HAPE. Tako uvedena alveolarna hipoksija dalje pogoršava hipoksemiju hemoglobinopatije i stvara se začarani krug. U ovom pregledu autori preporučuju laboratorijske eksperimente kako bi se dokazale ove hipoteze. Predloženi fiziološki mehanizam ima značajne terapijske implikacije. Ako se dokaže, autori predlažu primjenu izmjenske transfuzije kao dopunske terapije i razvoj lijekova protiv CD147.

Ključne riječi: COVID-19; Visinska plućna embolija; Visinski plućni edem, patofiziologija; Sindrom akutnog respiracijskog distresa; $C D 147$ 